\title{
RESEARCH
}

\section{Developmental role of PHD2 in the pathogenesis of pseudohypoxic pheochromocytoma}

\author{
Luise Eckardt1,2,*, Maria Prange-Barczynska1,3,*, Emma J Hodson4,5, James W Fielding1,3, Xiaotong Cheng1,3, \\ Joanna D C C Lima1', Samvid Kurlekar', Gillian Douglas', Peter J Ratcliffe ${ }^{1,3,4}$ and Tammie Bishop (D) \\ 1Target Discovery Institute, University of Oxford, Oxford, UK \\ IInstitute of Physiology and Pathophysiology, University of Heidelberg, Heidelberg, Germany \\ ${ }^{3}$ Ludwig Institute for Cancer Research, University of Oxford, Oxford, UK \\ ${ }^{4}$ The Francis Crick Institute, London, UK \\ 5The Department of Experimental Medicine and Immunotherapeutics, University of Cambridge, Cambridge, UK \\ ${ }^{6}$ BHF Centre of Research Excellence, Division of Cardiovascular Medicine, Radcliffe Department of Medicine, John Radcliffe Hospital, University of Oxford, \\ Oxford, UK
}

Correspondence should be addressed to P J Ratcliffe or T Bishop: peter.ratcliffe@ndm.ox.ac.uk or tammie.bishop@ndm.ox.ac.uk

*(L Eckardt and M Prange-Barczynska contributed equally to this work)

\begin{abstract}
Despite a general role for the HIF hydroxylase system in cellular oxygen sensing and tumour hypoxia, cancer-associated mutations of genes in this pathway, including PHD2, PHD1, EPAS1 (encoding HIF-2 $\alpha$ ) are highly tissue-restricted, being observed in pseudohypoxic pheochromocytoma and paraganglioma (PPGL) but rarely, if ever, in other tumours. In an effort to understand that paradox and gain insights into the pathogenesis of pseudohypoxic PPGL, we constructed mice in which the principal HIF prolyl hydroxylase, Phd2, is inactivated in the adrenal medulla using TH-restricted Cre recombinase. Investigation of these animals revealed a gene expression pattern closely mimicking that of pseudohypoxic PPGL. Spatially resolved analyses demonstrated a binary distribution of two contrasting patterns of gene expression among adrenal medullary cells. Phd 2 inactivation resulted in a marked shift in this distribution towards a Pnmt-/Hif- $2 \alpha^{+} /$Rgs5 $^{+}$population. This was associated with morphological abnormalities of adrenal development, including ectopic $\mathrm{TH}^{+}$cells within the adrenal cortex and external to the adrenal gland. These changes were ablated by combined inactivation of Phd 2 with Hif- $2 \alpha$, but not Hif- $1 \alpha$. However, they could not be reproduced by inactivation of Phd 2 in adult life, suggesting that they arise from dysregulation of this pathway during adrenal development. Together with the clinical observation that pseudohypoxic PPGL manifests remarkably high heritability, our findings suggest that this type of tumour likely arises from dysregulation of a tissue-restricted action of the PHD2/HIF-2 $\alpha$ pathway affecting adrenal development in early life and provides a model for the study of the relevant processes.
\end{abstract}

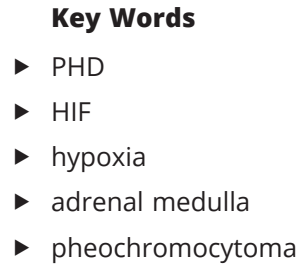

Endocrine-Related Cancer (2021) 28, 757-772 (c) 2021 The authors Published by Bioscientifica Ltd. Printed in Great Britain

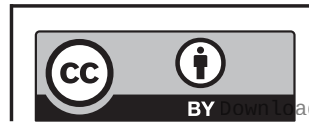

This work is licensed under a Creative Commons Attribution 4.0 International License. 


\section{Introduction}

Pheochromocytoma and paraganglioma (PPGL) are tumours of the autonomic paraganglia that arise in diverse anatomical locations from the skull base to the pelvis. Those found within the adrenal glands (AGs) are known as pheochromocytoma (PCC) and those in extra-adrenal structures including the carotid body are commonly termed paraganglioma (PGL). Molecular analysis of these tumours has revealed a number of subtypes or clusters, with distinct patterns of gene expression within the tumour being associated with different groups of tumourassociated mutations. Genetic profiling has revealed four such subtypes: kinase signalling, Wnt-altered, cortical admixture and pseudohypoxia (Crona etal. 2017, Fishbein \& Wilkerson 2018). The pseudohypoxia subtype (or Cluster I) is associated with mutations affecting transcriptional pathways induced by hypoxia.

The transcriptional response to hypoxia is mediated by hypoxia-inducible factor (HIF) (reviewed in Bishop \& Ratcliffe 2014), a heterodimer consisting of an oxygenregulated $\alpha$ and a constitutively expressed $\beta$ subunit. HIF- $\alpha$ is regulated by a series of 2-oxoglutarate-dependent dioxygenases that generate an oxygen-dependent signal by hydroxylation of specific prolyl residues in HIF- $\alpha$ subunits which are targeted for proteasomal degradation via the E3 ubiquitin ligase von Hippel-Lindau (VHL) protein. Mammalian species have multiple HIF- $\alpha$ isoforms, of which HIF-1 $\alpha$ and HIF- $2 \alpha$ are the most abundant and best studied. They also express three closely related isoforms of the HIF prolyl hydroxylase enzymes (PHD1, PHD2 and PHD3, otherwise known as EGLN2, EGLN1 and EGLN3), of which PHD2 is the most abundant and important regulator of HIF.

HIF is commonly activated in cancer and its role in oncogenesis has attracted widespread interest, particularly in view of the recent development of drugs with the potential to activate or inactivate components of the pathway therapeutically (reviewed in Semenza 2019, Choueiri \& Kaelin 2020). Nevertheless, this relationship of HIF activation to oncogenesis has proved more complex than anticipated. For instance, although HIF is commonly upregulated in cancer, direct genetic activation by mutation of any of the key components of the pathway is rare in most forms of cancer.

The pseudohypoxic subtype of PPGLs is an important exception. These tumours manifest a 'pseudohypoxic' pattern of gene expression encompassing upregulation of certain HIF target genes, together with alterations in the expression of differentiation markers (Dahia et al.
2005, Favier et al. 2009, 2012, Waldmann et al. 2010, Burnichon et al. 2011, Lorenzo et al. 2013, Toledo et al. 2013, Welander et al. 2014, Yang et al. 2015, Fishbein et al. 2017). They are associated with loss-of-function mutations in VHL, PHD2 and PHD1 and gain-of-function mutations in HIF-2 $\alpha$ (otherwise known as EPAS1) as well as mutations in genes encoding the tricarboxylic acid cycle enzymes succinate dehydrogenase $(S D H B / D / C / A$ or $S D H x)$ and fumarate hydratase $(F H)$ (Dahia et al. 2005, Ladroue et al. 2008, Zhuang etal. 2012, Yang etal. 2015). Impaired function of the latter two enzymes leads to the accumulation of succinate and fumarate, respectively, which are able to inhibit 2-oxoglutarate-dependent dioxygenases including the HIF prolyl hydroxylases. All these mutations therefore have the potential to activate HIF, suggesting that in this setting it is HIF that provides the oncogenic drive.

However, there are a number of puzzling features in these associations. First, PPGLs in general manifest an unusually high ratio of inherited to sporadic forms. For instance, up to $40 \%$ of PPGLs are associated with germline or post-zygotic but very early somatic mutation, as assessed by family history or distribution of mutant cells (Buffet et al. 2020). Secondly, the spectrum of gene dysregulation in pseudohypoxic PPGLs does not align exactly with that of dynamically regulated HIF transcriptional targets (Dahia et al. 2005, Favier et al. 2009, 2012, Waldmann et al. 2010, Burnichon et al. 2011, Lorenzo et al. 2013, Toledo et al. 2013, Welander et al. 2014, Yang et al. 2015, Fishbein et al. 2017). Thirdly, human VHL mutations associated with PCCs have a complex relationship to dysregulation of HIF: type 1 VHL mutations, which show complete dysregulation of HIF, are not associated with pheochromocytoma whereas type $2 \mathrm{~A}, \mathrm{~B}$ and $\mathrm{C} V H L$ mutations, which are associated with pheochromocytoma, show either less severe or no dysregulation of HIF, at least when assayed in vitro or in heterologous cell types (Kaelin 2008). Fourthly, $V h l$ inactivation in the adrenal medulla (AM) and carotid body of the mouse results in tissue atrophy rather than tumour formation (Macias et al. 2014).

In an attempt to shed light on these paradoxical findings and better understand the role of activation of HIF pathways in the AM, we have examined the effects of inactivation of the principal HIF prolyl hydroxylase Phd2 in the AM, using Cre recombinase restricted by the tyrosine hydroxylase (TH) promoter, in the mouse. We report that TH-restricted constitutive inactivation of $P h d 2$ in the AM results in a 'pseudohypoxic pattern' of gene expression in which dynamic activation of HIF transcription is superimposed on a developmental shift in populations of AM cells manifesting specific patterns of

This work is licensed under a Creative Commons Attribution 4.0 International License. 
gene expression associated with the presence or absence of phenylethanolamine $N$-methyltransferase (PNMT). Changes in gene expression were accompanied by morphological abnormalities including ectopic $\mathrm{TH}^{+}$cells within the adrenal cortex and in peri-adrenal structures. These findings, together with marked differences between constitutive and inducible inactivation of $P h d 2$ in adult life, suggest that the pathological activation of the PHD2/ HIF-2 pathway during adrenal development is critical for its tumourigenic action.

\section{Methods}

\section{Ethical approval and animals}

Animal experimental protocols were approved by the University of Oxford Medical Science Division Ethical Review Committee and are compliant with the UK Home Office Animals (Scientific Procedures) Act 1986. Experiments were performed on $\sim 3$ month-old mice and sex-matched controls, unless stated otherwise. Mice were kept in individually ventilated cages with free access to water and food. Phd2f/f, Hif- $1 \alpha^{f / f}$ and Hif-2 $\alpha^{f / f}$ alleles are as described (Cramer et al. 2003, Gruber et al. 2007, Mazzone et al. 2009). Note that Phd2 is equivalent to $E g \ln 1$ and Hif-2 $\alpha$ is equivalent to Epas1; we have used the Phd $2 /$ Hif- $2 \alpha$ terminology to simplify mechanistic interpretation for the reader. $\mathrm{TH}^{+}$cell-specific inactivation was achieved using the constitutively expressed TH-IRESCre (THCre; Lindeberg et al. 2004) or inducible TH-IRESCreER (THCreER; Rotolo et al. 2008) and ubiquitous inactivation using the inducible Rosa26Cre ERT2 (RosaCreER; Vooijs et al. 2001). Each mouse line was backcrossed with C57BL/6 for at least five generations.

\section{Drug administration}

For adult-onset Phd2 inactivation, $\sim 6$ week-old mice were dosed once daily with $2 \mathrm{mg}$ tamoxifen orally $(20 \mathrm{mg} / \mathrm{mL}$ in corn oil containing 10\% ethanol, Sigma) for 5 consecutive days. Phd2f/f;RosaCreER and Phd2f/f;THCreER mice were sacrificed 17 days or $\sim 3$ months, respectively, after the start of treatment.

\section{Tissue collection}

Animals were killed by an overdose of isoflurane (Piramal Critical Care, West Drayton, UK) and exsanguination from the inferior vena cava. Blood was collected using heparinised needles. AGs for RT-qPCR were dissected into ice-cold phosphate buffered saline (PBS, in $\mathrm{mM}$ : $\left.137 \mathrm{NaCl}, 2.7 \mathrm{KCl}, 4 \mathrm{Na}_{2} \mathrm{H}_{2} \mathrm{PO}_{4} .7 \mathrm{H}_{2} \mathrm{O}, 1.5 \mathrm{KH}_{2} \mathrm{PO}_{4}\right)$ in diethyl pyrocarbonate-treated water $(0.1 \%$, v/v, Sigma). For histology, mice were perfused-fixed with $5 \mathrm{~mL}$ PBS followed by $5 \mathrm{~mL} \mathrm{4 \%}$ paraformaldehyde (PFA)/PBS (w/v) (Sigma). Dissected AGs were fixed in 4\% PFA/PBS overnight, transferred into $70 \%(\mathrm{v} / \mathrm{v})$ ethanol then dehydrated in an ascending ethanol series ending in histoclear (National Diagnostics, Atlanta, US), embedded in $60^{\circ} \mathrm{C}$ paraffin and sectioned to $4 \mu \mathrm{m}$ thickness with a Microm HM $355 \mathrm{~S}$ microtome (Thermo Fisher Scientific).

\section{Catecholamine measurements}

Blood was centrifuged at $800 \boldsymbol{g}$ for $5 \mathrm{~min}$ and plasma was separated and stored at $-80^{\circ} \mathrm{C}$. Adrenaline and noradrenaline were detected in diluted plasma samples using the Epinephrine/Norepinephrine ELISA Kit (KA1877, Abnova, Taoyuan City, Taiwan). Signal absorbance was read at $450 \mathrm{~nm}$ using a FLUOstar Omega microplate reader (BMG Labtech, Aylesbury, UK). Catecholamine concentrations were calculated using a linear standard curve.

\section{Immunohistochemistry}

Sections were immunostained for TH using an EnVision+ kit (Dako Denmark A/S) with a polyclonal rabbit anti-TH antibody (1:5000, NB300-109, Novus Biologicals, Cambridge, UK) (Bishop et al. 2013).

\section{In situ hybridisation}

mRNA was detected in sections using the manual RNAScope 2.5 HD BROWN assay or, for dual in situ hybridisation, the RNAScope 2.5 HD Duplex assay (Advanced Cell Diagnostics, Newark, US). RNAScope probes: Mm-Pnmt (426421 or 426421-C2 for dual RNAScope), Mm-Epas1 (314371), Mm-Rgs5 (430181), Mm-Vegfa-OI (43961). Imaging was performed with a Leica DM 1000 LED microscope (Leica Biosystems).

\section{Proximity ligation in situ hybridisation (PLISH)}

Multiplex fluorescence in situ hybridisation was performed using PLISH (Nagendran et al. 2018). Sections were de-paraffinised, boiled in a $10 \mathrm{mM}$ citrate buffer (pH 6.0) with $0.05 \%$ lithium dodecyl sulfate (Sigma) and processed in sealed hybridisation chambers (Grace Biolabs, Bend, US). Tissues were treated with 
$0.1 \mathrm{mg} / \mathrm{mL}$ Pepsin (Roche-10108057001, Sigma-Aldrich) in $0.1 \mathrm{M} \mathrm{HCl}$, followed by (at $37^{\circ} \mathrm{C}$ ): hybridisation of barcoded gene probes and bridge sequences, DNA ligation (10 CEU/mL T4 DNA ligase, M0202T, New England Biolabs, Ipswich, US) and extension by rolling circle amplification (1 U/mL Nxgen phi29 polymerase, Lucigen, Middleton, US). Samples were incubated with fluorophore-conjugated oligonucleotides specific to the barcode for the targeted gene probe (Supplementary Methods, see section on supplementary materials given at the end of this article), washed then treated with TruVIEW autofluoresence quenching kit (Vector Laboratories, Burlingame, US), stained with DAPI and mounted. Imaging was performed with a Zeiss Axio Imager M1 microscope (Jena, Germany) and analysed with Qupath software (Bankhead et al. 2017).

\section{Morphometric analysis}

AM volume was modelled by measuring the $\mathrm{TH}^{+}$area of one in eight consecutive slides of the AG using ImageJ software (NIH) (Bishop et al. 2008, Fielding et al. 2018). In situ hybridisation signal was quantified using trainable Weka segmentation plugin in Fiji ImageJ 1.53c software (NIH) (Cheng et al. 2020).

\section{RT-qPCR}

AGs were collected from five mice per genotype and AMs sub-dissected under an SMZ-745 stereo microscope (Nikon) and stored in RNAProtect (Qiagen) on ice. Pooled tissues were homogenised in RLT+ buffer (Qiagen) using a ProScientific PRO200 Homogenizer (Cole-Parmer, Eaton Socon, UK). RNA was isolated using the RNeasy Plus Micro Kit (Qiagen), cDNA prepared using the QuantiTect RT Kit (Qiagen) and RT-qPCR performed with the TaqMan Fast Advanced Master Mix Kit (Thermo Fisher Scientific) in the StepOnePlus Real-Time PCR System (Applied Biosystems). Three technical replicates were used in each biological repeat with Actb serving as a reference gene (see Supplementary methods for TaqMan probes). Fold change in gene expression was reported as $2-\Delta \Delta C \mathrm{CT}$, where $\Delta \Delta \mathrm{C}_{\mathrm{T}}=$ Phd2f/f;THCre $\left(\mathrm{C}_{\mathrm{T}}\right.$ target $-\mathrm{C}_{\mathrm{T}}$ reference $)-P h d 2^{f / f}$ $\left(\mathrm{C}_{\mathrm{T}}\right.$ target $-\mathrm{C}_{\mathrm{T}}$ reference $)$.

\section{Statistical analysis}

Data are shown as mean \pm S.E.M. Statistical analyses were performed using unpaired Student's $t$-tests, unless otherwise stated, and using GraphPad Prism 9.0 Software.

\section{Results}

Since pseudohypoxic PPGLs have a characteristic gene expression profile, we first sought to test whether and to what extent this was mimicked by $P h d 2$ inactivation in the AM. To this end, we intercrossed mice bearing a conditionally inactivated $(P h d 2 f / f)$ allele with a transgenic line expressing Cre recombinase restricted by the $\mathrm{TH}$ promoter (THCre) to generate Phd2fff;HCre mice and measured effects on the expression of a panel of 14 genes that are frequently dysregulated in pseudohypoxic PPGLs (Supplementary Table 1). This comprised several classes of genes, including HIF target genes Vegfa, Slc2a1 and Ldha; atypical mitochondrial subunits Ndufa4l2 and Cox4i2; G-protein signalling pathway components Rgs4, Rgs5 and Adora2a; Pnmt, the terminal enzyme in catecholamine synthesis; genes with oncogenic potential including Stc1.

These experiments revealed that many, though not all, genes identified as dysregulated in pseudohypoxic PPGLs were also dysregulated in a similar way in the AM of Phd2fff;HCre mice (Fig. 1A), suggesting that their expression is directly or indirectly altered as a consequence of dysregulation of the PHD2/HIF system in this setting. Interestingly, not all these genes have been identified as being dynamically regulated by HIF itself in the manner observed. In particular, Pnmt has been reported to be upregulated by HIF-1 in rat pheochromocytoma PC12 cells (Tai et al. 2009), whereas we observed striking downregulation of Pnmt (mRNA and protein) with Phd2 inactivation/HIF activation (Fig. 1A and Supplementary Fig. 1). PNMT is the terminal enzyme in the catecholamine synthesis pathway which converts noradrenaline into adrenaline. In keeping with the loss of Pnmt, we observed a shift in plasma catecholamines: an increase in noradrenaline together with a reduction in adrenaline (Fig. 1B). This predominantly noradrenergic secretory profile, together with a loss of Pnmt expression, is similar to clinical observations in patients with pseudohypoxic PCCs (Eisenhofer et al. 2001).

We therefore sought to determine whether Phd2ff; THCre mice have morphological features of PCC, in particular evidence of intra-adrenal pathology. However, no frank tumours, nodules, cortical compression or loss of nest-like/formation of sheet-like chromaffin cell clusters (Smith-Hicks et al. 2000, Park et al. 2015) were observed, and there was no change in overall AM volume or proliferation (Supplementary Table 2).

However, we noted striking abnormalities of adrenal morphology, in particular the abnormal location of $\mathrm{TH}^{+}$ cells. These comprised clusters of ectopic cells in the https://erc.bioscientifica.com https://doi.org/10.1530/ERC-21-0211 (c) 2021 The authors Published by Bioscientifica Ltd. Printed in Great Britain
This work is licensed under a Creative Commons Attribution 4.0 International License. ed from Bioscientifica.com at 04/26/2023 11:46:24AM 
A

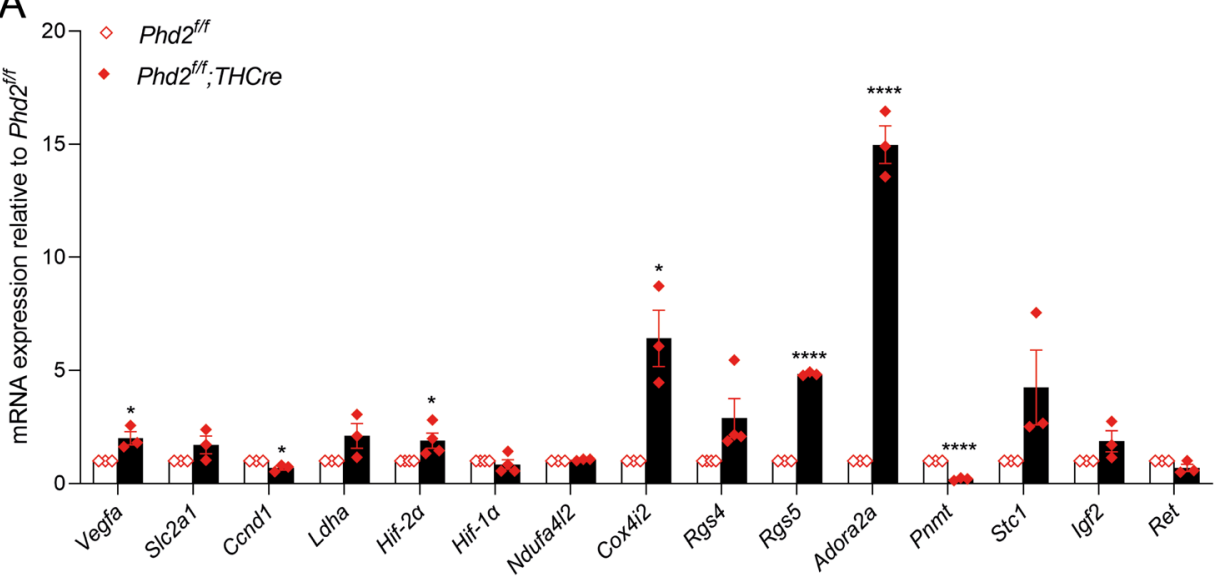

C

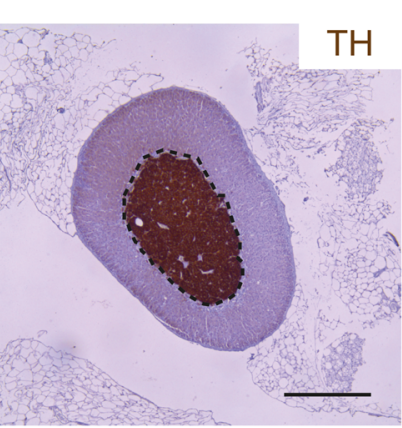

Phd2ff

$\mathrm{TH}$

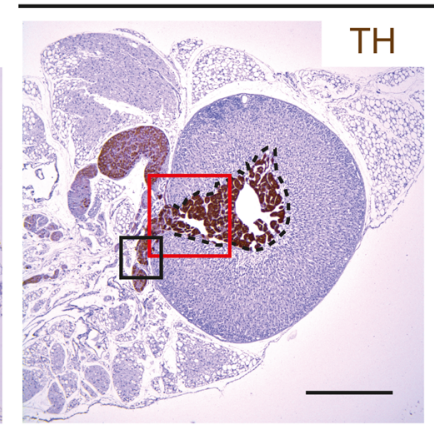

B

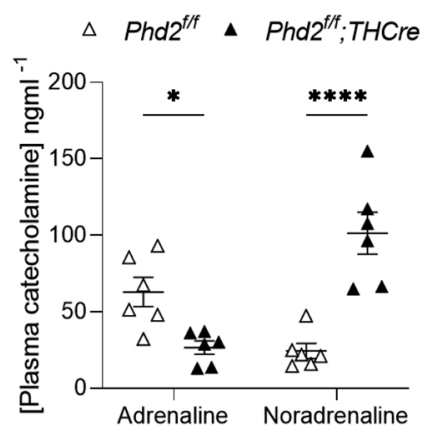

\section{Figure 1}

Effect of TH-restricted Phd2 inactivation on gene expression, plasma catecholamines and AM morphology. (A) Gene expression profile of AMs in Phd2ff; THCre mice (relative to Phd2fff controls), analysed by RT-qPCR on RNA extracted from ten AMs per biological replicate. Data for individual genes were analysed by unpaired two-tailed Student's $t$-tests. Gene expression pattern in Phd2ff; THCre AMs resembles that of pseudohypoxic PPGLs. (B) Plasma catecholamine levels in Phd2ff; THCre (vs Phd2fff control) mice. Data were analysed by a two-way ANOVA, interaction (Phd2 inactivation vs noradrenaline/ adrenaline ratio) $P<0.0001$ followed by Sidak's multiple comparisons test. Graph shows a reduction in adrenaline and an increase in noradrenaline in the plasma of Phd2ff; THCre mice. (C) Representative images of Phd2ff; THCre (compared with Phd2fff control) AGs. The AM is encircled with a black dashed line in this and other figures. TH antibody (brown); Harris haematoxylin counterstain (blue). Enlarged images show ectopic TH+ cells in the adrenal cortex (red frame) and in a peri-adrenal structure (black frame). Scale bars: $0.5 \mathrm{~mm}$ (far and middle left panels); $0.1 \mathrm{~mm}$ (red frame); $0.05 \mathrm{~mm}$ (black frame).

Data show mean \pm S.E.M. ${ }^{\star} P<0.05, * \star \star \star * P<0.0001$

adrenal cortex that disrupt the outer cortical boundary, adjacent to a $\mathrm{TH}^{+}$extra-adrenal ganglion-like structure (Fig. 1C). Altogether, 11 out of 14 Phd2ff; ; THCre mice and 0 out of 15 littermate controls manifest these abnormalities.

$\mathrm{TH}^{+}$chromaffin cells migrate through the adrenal cortex to reach their final destination in the AM (Furlan et al. 2017, Hanemaaijer et al. 2021), during which time they acquire Pnmt expression in the final stages of maturation to become adrenergic (Verhofstad et al. 1979). We therefore considered whether the abnormally located $\mathrm{TH}^{+}$cells (both within and directly adjacent to the AG) represent abnormal migration of chromaffin cells and that the reduction in Pnmt might also reflect failure to acquire Pnmt due to dysregulated/ arrested development with Phd2 inactivation.

To address this, we proceeded to analyse the spatial distribution of gene expression within the AM. The normal
AG is known to express Pnmt in a restricted set of mature chromaffin cells that produce adrenaline (Coupland \& Hopwood 1966). Analysis of the spatial distribution of Pnmt expression in WT mice confirmed this, with the majority ( 75\%) of chromaffin cells expressing Pnmt (Fig. $2 \mathrm{~A})$. We next considered whether this expression pattern extended to other genes which were dysregulated in AMs with loss of Phd2. The following genes were selected for analysis: Hif-2 $\alpha$, since its upregulation is characteristic of VHL-associated neoplasia including PCCs (Toledo 2017); Vegfa and Rgs5, since these are reported HIF target genes (Jin et al. 2009, Fielding et al. 2018) and the latter is also a proposed regulator of chromaffin cell differentiation (Chan et al. 2019, Hanemaaijer et al. 2021). These experiments revealed a striking inverse pattern of gene expression, with Hif-2 $\alpha$ and Rgs 5 mRNA being expressed 


\section{Endocrine-Related \\ Cancer}

A
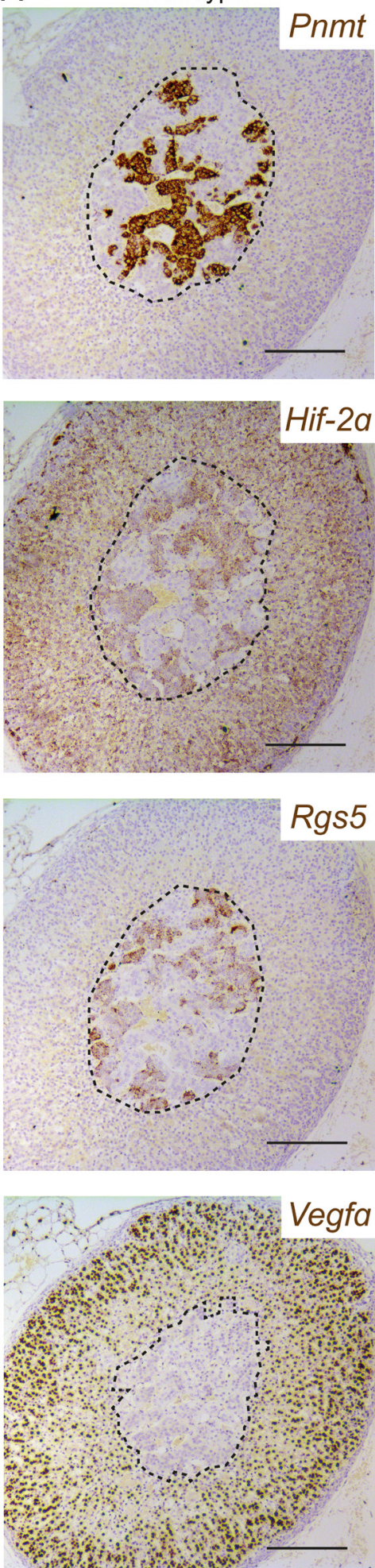

B
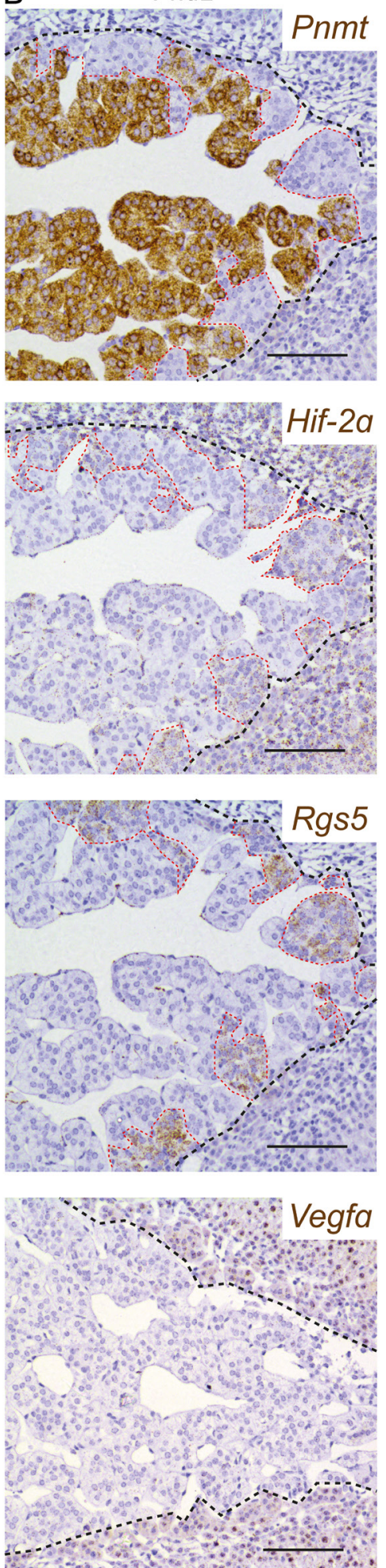
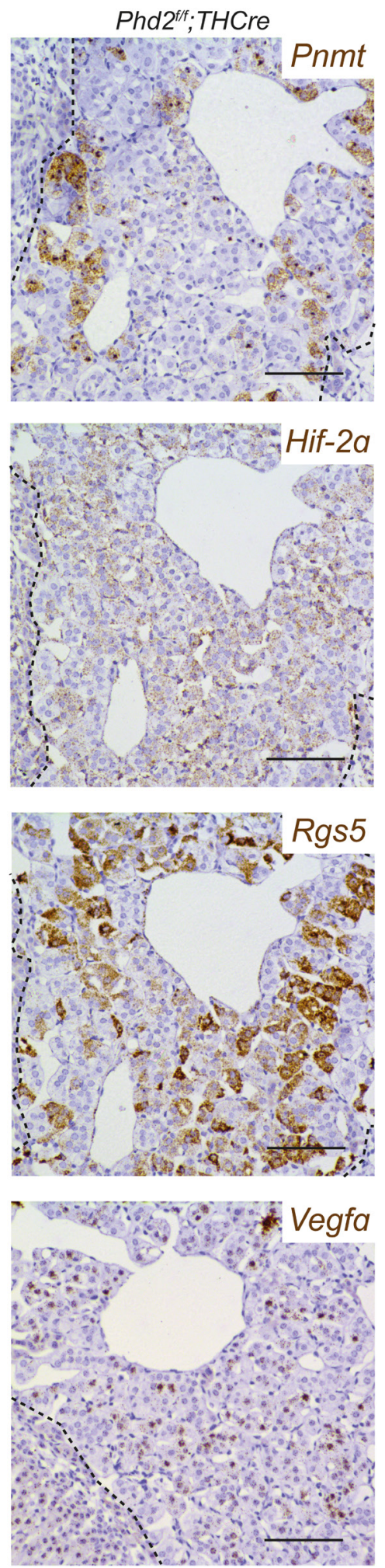

\section{Figure 2}

Effect of Phd 2 inactivation on the spatial expression of genes in the AM. (A) In situ hybridisation for Pnmt, Hif-2 $\alpha$, Rgs 5 and Vegfa mRNA (brown) in adjacent sections of a WT AG showing Hif-2 $\alpha$ and Rgs5 mRNA expression in Pnmt- cells. Gill's haematoxylin counterstain (grey-blue). Scale bars: 0.2 mm. (B) Comparison of Pnmt, Hif-2 $\alpha$, Rgs5 and Vegfa mRNA expression in Phd2fff vs Phd2ff; THCre AMs. Red dashed lines outline Pnmt-/Hif-2 $\alpha^{+} /$Rgs $5^{+}$cell populations in this and other figures. Images show a switch from predominantly Pnmt $/ / H i f-2 \alpha^{-} /$Rgs5- to Pnmt- $/ H i f-2 \alpha^{+} /$Rgs $5^{+}$cells following Phd 2 inactivation. Harris haematoxylin counterstain (blue). Scale bars: $0.1 \mathrm{~mm}$.

https://erc.bioscientifica.com

https://doi.org/10.1530/ERC-21-0211 (c) 2021 The authors Published by Bioscientifica Ltd. Printed in Great Britain
This work is licensed under a Creative Commons Attribution 4.0 International License. 


\section{Endocrine-Related} Cancer L Eckardt, M Prange-
Barczynska et al.
The role of PHD2 in

pseudohypoxic PCCs
28:12 only in the normal AM cells that do not express Pnmt (Fig. 2A). Vegfa, on the other hand, could not be detected, except in the adrenal cortex where it was strongly expressed (Fig. 2A). This suggested the possibility that a binary, cellspecific pattern of expression exists within AM cells, with low Pnmt associating with high Hif- $2 \alpha$ and upregulation of at least some of its transcriptional targets such as Rgs5.

The findings therefore raised the interesting question as to whether inactivation of Phd2 might affect the expression of these genes (Pnmt, Hif-2 $\alpha, R g s 5$ and $V e g f a)$ within a specific population of cells or whether the prevalence of the two populations manifesting the observed patterns of gene expression might change after Phd2 inactivation. To address this, we performed further in situ mRNA hybridisation studies. These studies revealed

A
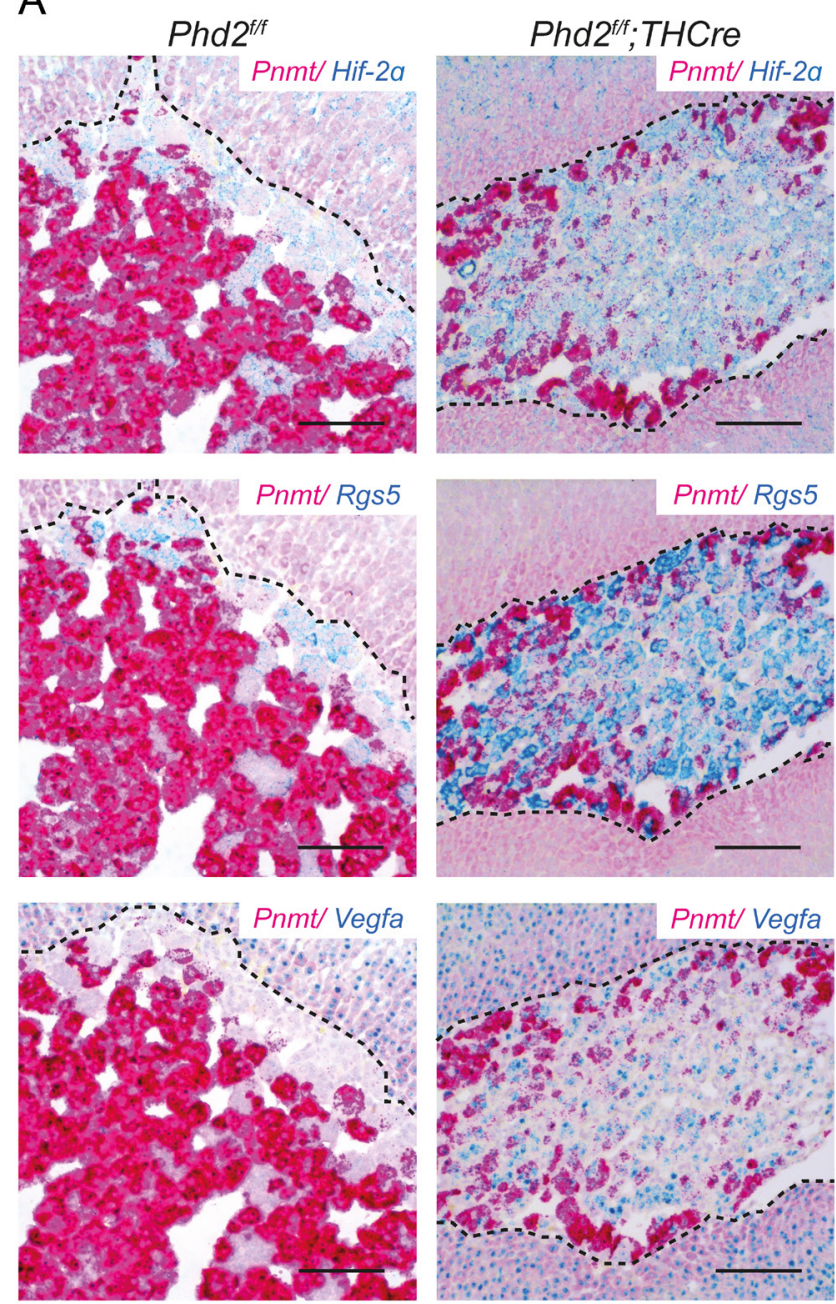

a major switch of cell populations in AMs following Phd2 inactivation. The same pattern of Pnmt-/Hif-2 $\alpha^{+} /$Rgs $^{+}$ was maintained, but cells manifesting this pattern now became the dominating cell population distributed across most of the AM with the exception of small areas around the periphery (Fig. 2B). Within the dominating population of Pnmt-/Hif-2 $\alpha^{+} / \mathrm{Rgs}^{+}$expressing cells, there was also a mild induction of the HIF target gene Vegfa (Fig. 2B).

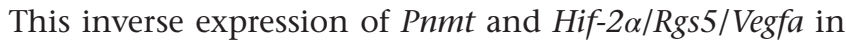
Phd2f/f and Phd2f/f;THCre AMs was confirmed by dual in situ hybridisation and PLISH, which allow multiplexing of different mRNA probes to measure overlapping patterns of expression (Fig. 3 and Supplementary Fig. 2).

We next went on to examine the ectopic $\mathrm{TH}^{+}$cells within the adrenal cortex. Interestingly, essentially

B
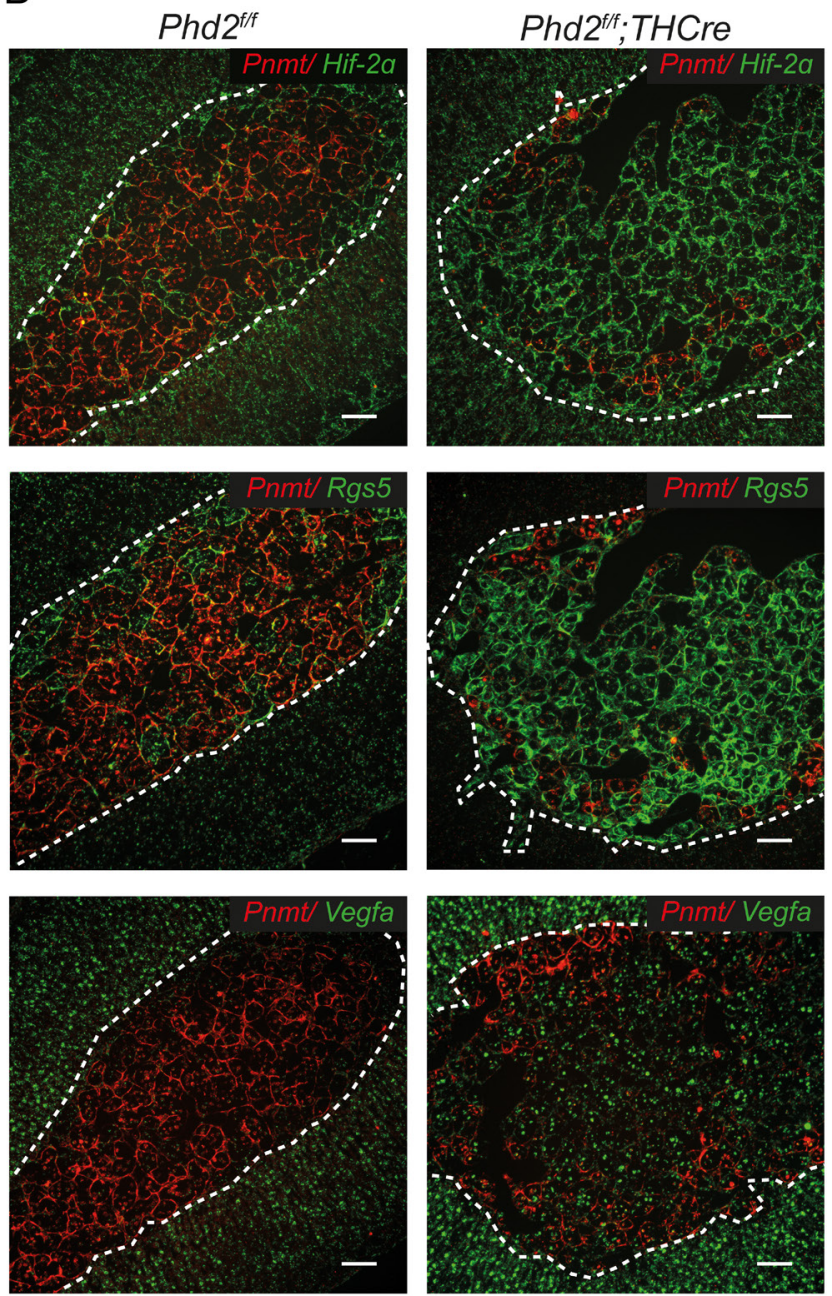

Figure 3

Spatial co-localisation of genes in the AM. (A) Dual in situ hybridisation or (B) proximity ligation in situ hybridisation (PLISH) for Pnmt, Hif-2 $\alpha$, Rgs5 and Vegfa mRNA in Phd2f/f and Phd2ff; THCre AMs. Pnmt expression in cells inversely correlates with Hif-2 $\alpha$ and Rgs5 in both genotypes but Pnmt $/$ Hif-2 $\alpha^{-} /$Rgs5- cell

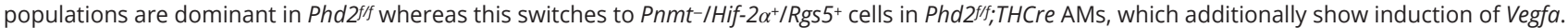
For dual in situ hybridisation, Gill's haematoxylin counterstain (grey-blue). Scale bars for dual in situ hybridisation: $0.1 \mathrm{~mm}$, for PLISH: $0.05 \mathrm{~mm}$.

https://erc.bioscientifica.com https://doi.org/10.1530/ERC-21-0211 (c) 2021 The authors Published by Bioscientifica Ltd. Printed in Great Britain
This work is licensed under a Creative Commons Attribution 4.0 International License. ed from Bioscientifica.com at 04/26/2023 11:46:24AM 
all these cells were Pnmt- $/ \mathrm{Hif}-2 \alpha^{+} / \mathrm{Rgs}^{+} / \mathrm{Vegfa}^{+}$(Fig. 4) (and negative for the adrenal cortical cell marker Cyp11a1, Supplementary Fig. 3), again suggestive of arrested migration of an immature Pnmt- $^{-}$population of chromaffin cells within the adrenal cortex during development. Taken together, these experiments suggest that TH-restricted $P h d 2$ inactivation results in a pattern of gene expression similar to that of pseudohypoxic PPGLs. Morphological abnormalities suggestive of an effect on adrenal development were coupled to a major switch in an apparently binary pattern of gene expression observed in populations of cells within the AM.

To further understand this process, we intercrossed

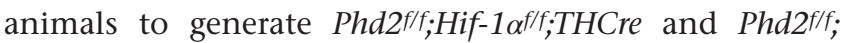
Hif-2 $\alpha^{f / f}$;THCre mice, which were examined with respect to the above phenotypes. No reversion of the morphological phenotype was observed with concomitant Hif-1 $\alpha$ inactivation (Fig. 5). In striking contrast, Hif-2 $\alpha$ inactivation (Phd2f/f;Hif-2 $\alpha^{f / f}$; THCre mice) completely reversed all the morphological abnormalities associated with Phd2 inactivation, such that AMs were similar to those of control (Phd2f/f) mice (Fig. 5). Similar results were obtained with analysis of Pnmt, Rgs5 and Vegfa gene expression. The inverse expression pattern of Pnmt and Rgs5 was invariant, but the proportion of cells of each type was strikingly different, with Phd2fff;Hif-1 $\alpha^{f / f}$;THCre mice retaining a dominant population of $P n m t^{-} / R_{g s} 5^{+}$cells while Phd2f/f;Hif-2 $\alpha^{f / f} ;$ THCre mice apparently reverted to a phenotype indistinguishable from controls, including loss of Vegfa mRNA (Fig. 5). Together, this indicates that $H i f-2 \alpha$, not Hif- $1 \alpha$, is necessary for the abnormal phenotype resembling pseudohypoxic PCCs.

We therefore hypothesised that inactivation of Phd2 might have at least two distinct effects in order to generate this pseudohypoxic phenotype: first, a dynamic induction of HIF transcriptional target genes including Vegfa; secondly, a switch to an immature noradrenergic cellular phenotype within the AM. Since we also observed morphological abnormalities suggestive of interrupted differentiation and/or migration, we sought to determine whether these components of the pseudohypoxic phenotype might reflect an action of the PHD2/HIF-2 axis during differentiation. To test this, we proceeded to compare the effects with those in animals where inactivation of $P h d 2$ was restricted to adult life, using two different models. We analysed adult Phd2fff;THCreER at 3 months after inducing recombination with tamoxifen. To assess any effect of more extensive recombination, adult $P h d 2^{f f}$; RosaCreER mice were also studied. Since these develop systemic abnormalities (Hodson et al. 2016), they were studied somewhat earlier, approximately 17 days after tamoxifen dosing.

In striking contrast to Phd2f/f;THCre mice, inactivation of $P h d 2$ in adult mice by either protocol did not result in morphological abnormalities or a change in the spatial distribution of Pnmt- and Pnmt ${ }^{+}$cells (Fig. 6). Additionally, no change in AM volume or proliferation was noted (Supplementary Table 2). In contrast, induction of Rgs5 and Vegfa mRNA was observed in both models of adultonset Phd2 inactivation and was apparently confined to the population of cells that did not express Pnmt and were Hif- $2 \alpha^{+}$(Figs 6, 7 and Supplementary Fig. 4). Together, this suggests that two distinct effects of HIF-2 activation contribute to the pseudohypoxic phenotype observed with TH-restricted Phd2 inactivation: first, as a regulator of chromaffin cell differentiation during development; secondly, as a dynamic regulator of HIF target gene expression within Hif-2 $\alpha$ expressing cells.

\section{Discussion}

Our findings demonstrate that TH-restricted inactivation of $P h d 2$ results in a pattern of gene expression within the AM that resembles pseudohypoxic PPGLs. Importantly, several lines of evidence reveal that in addition to dynamic activation of the HIF transcriptional response, this alteration in gene expression reflects developmental consequences of Phd2 inactivation on the AM. First, the alteration in gene expression involves spatial changes in cell-specific patterns of gene expression that reflect lack of terminal differentiation to $\mathrm{Pnmt}^{+}$cells. Secondly, several of the genes involved in the altered pattern of expression, including Pnmt and Hif-2 $\alpha$ itself, are not dynamic HIF transcriptional targets. Thirdly, altered patterns of gene expression were associated with morphological abnormalities, including ectopic $\mathrm{TH}^{+}$cell populations with a Pnmt- pattern of gene expression. Finally, neither the spatial change in gene expression within the AM nor the morphological abnormalities in the position of $\mathrm{TH}^{+}$cells could be induced by Phd2 inactivation in adult life.

These findings are of particular interest when considered alongside several unusual observations on the clinical genetics of PPGL. Mutations that directly affect components of the PHD-HIF system are frequently observed in the uncommon syndrome of pseudohypoxic PPGL, but rarely, if ever, seen in other much more common forms of cancer. This is surprising since dynamic regulation of the transcriptional response

This work is licensed under a Creative Commons Attribution 4.0 International License. 

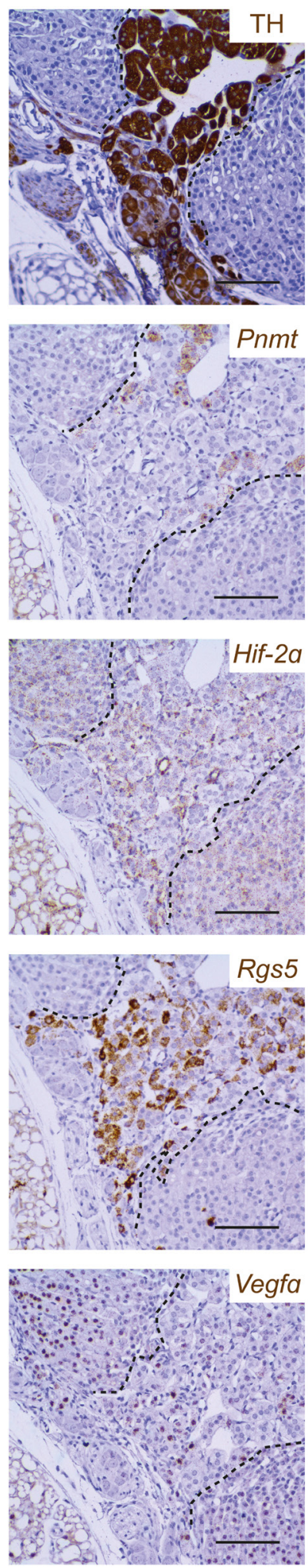
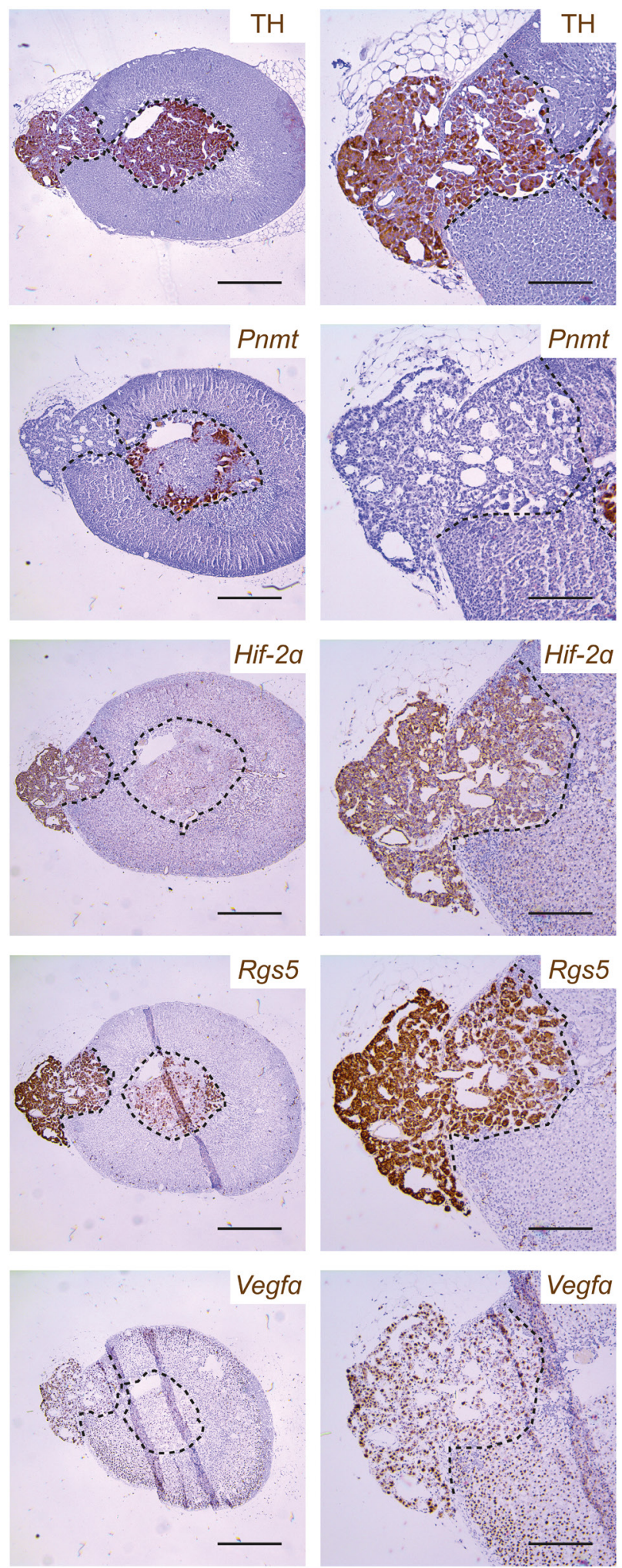

\section{Figure 4}

Gene expression profile of the ectopic $\mathrm{TH}^{+}$cell tracks in adrenal glands from Phd2ff; $\mathrm{THCre}$ mice. Representative images of ectopic $\mathrm{TH}^{+}$cells in the adrenal cortex from two different adrenal glands (left vs middle and right hand columns) from Phd2ff; THCre mice showing TH protein and Pnmt, Hif-2 $\alpha$, Rgs 5 and

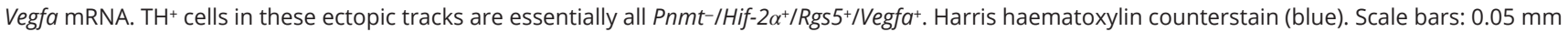
(left column), $0.5 \mathrm{~mm}$ (middle column), $0.2 \mathrm{~mm}$ (right column).

https://erc.bioscientifica.com

https://doi.org/10.1530/ERC-21-0211 (c) 2021 The authors Published by Bioscientifica Ltd. Printed in Great Britain
This work is licensed under a Creative Commons Attribution 4.0 International License.

ded from Bioscientifica.com at 04/26/2023 11:46:24AM 

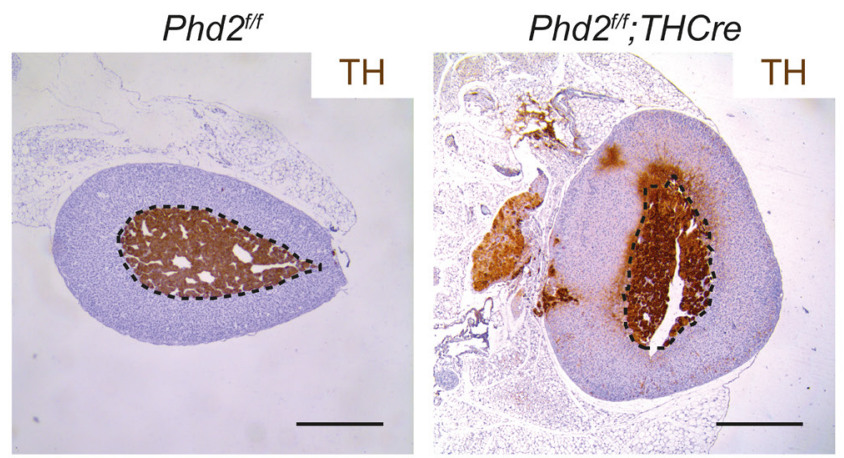

Phd2 $2^{\text {fff }} ;$ Hif-1 $\alpha^{f f f} ;$ THCre

Phd2 $2^{\text {fff }} ;$ Hif-2 $\alpha^{f f f} ;$ THCre
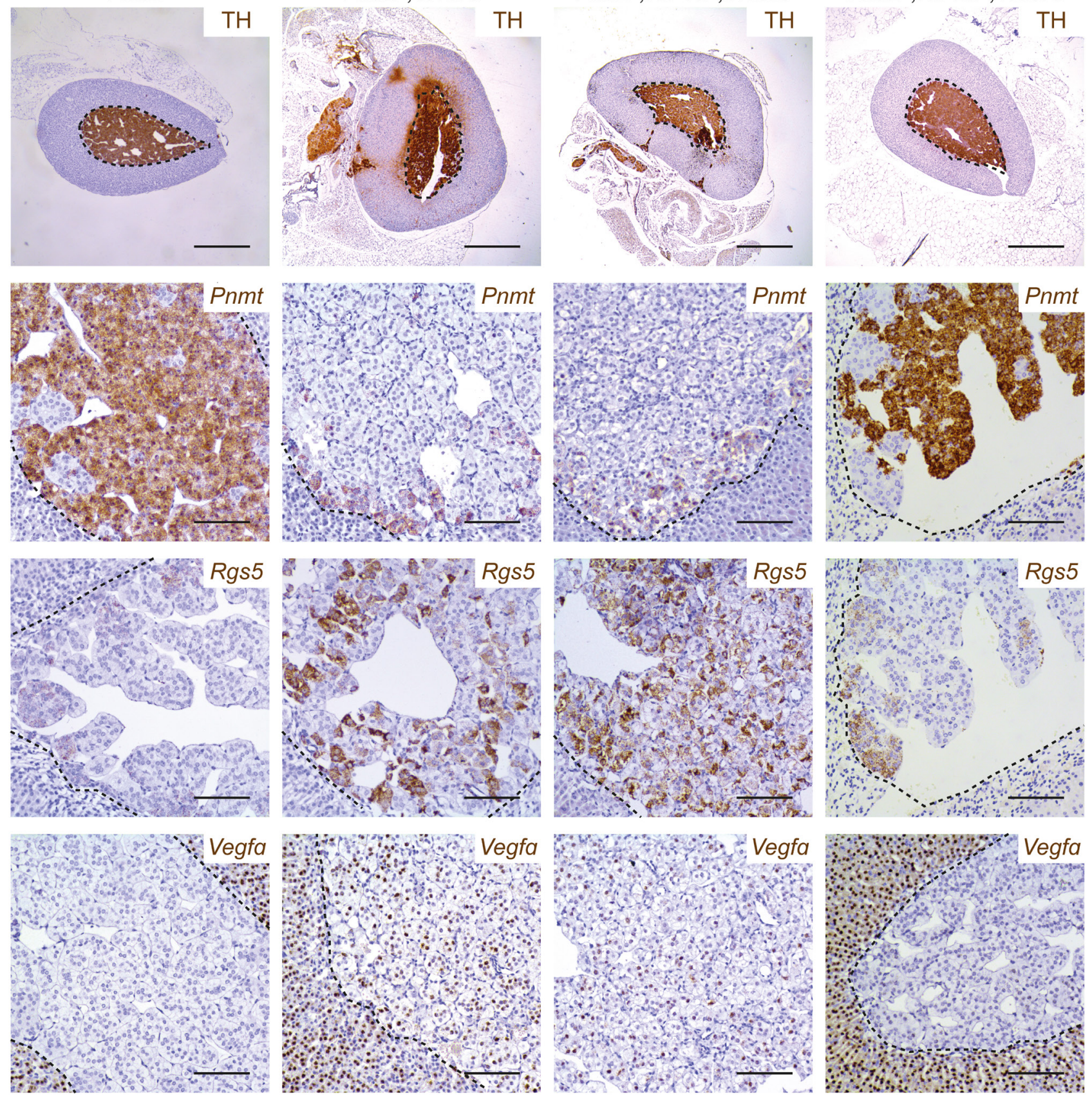

Figure 5

Effect of combined Hif- $\alpha$ and Phd2 inactivation on morphological abnormalities and gene expression in the AM. Representative images of TH

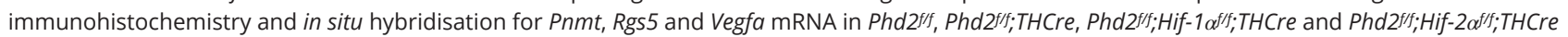
AMs. Concomitant inactivation of Hif-2 $\alpha$ and Phd2 (but not Hif- $1 \alpha$ and Phd2) reverses the morphological and gene expression changes observed in Phd2ff; THCre mice such that these AMs resemble those of control (Phd2ff) mice. Harris haematoxylin counterstain (blue). Scale bars: $0.5 \mathrm{~mm}$ (top row), $0.1 \mathrm{~mm}$ (lower panels).

to hypoxia by the PHD-HIF system is a general function observed in all cells. In addition, pseudohypoxic PPGL is associated with a very much higher incidence of germline (or post-zygotic but early somatic) mutations vs sporadic mutations, as compared to other forms of neoplasia.

https://erc.bioscientifica.com

https://doi.org/10.1530/ERC-21-0211

(c) 2021 The authors Published by Bioscientifica Ltd. Printed in Great Britain
Our findings suggest a mechanism by which these apparently paradoxical findings could be explained. Specifically, the observation that dysregulation of the PHDHIF system has a tissue-specific action on AM development suggests that these tumours have origins in early life, with

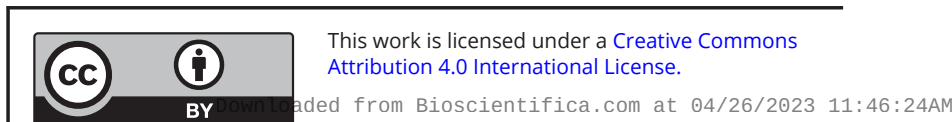


A
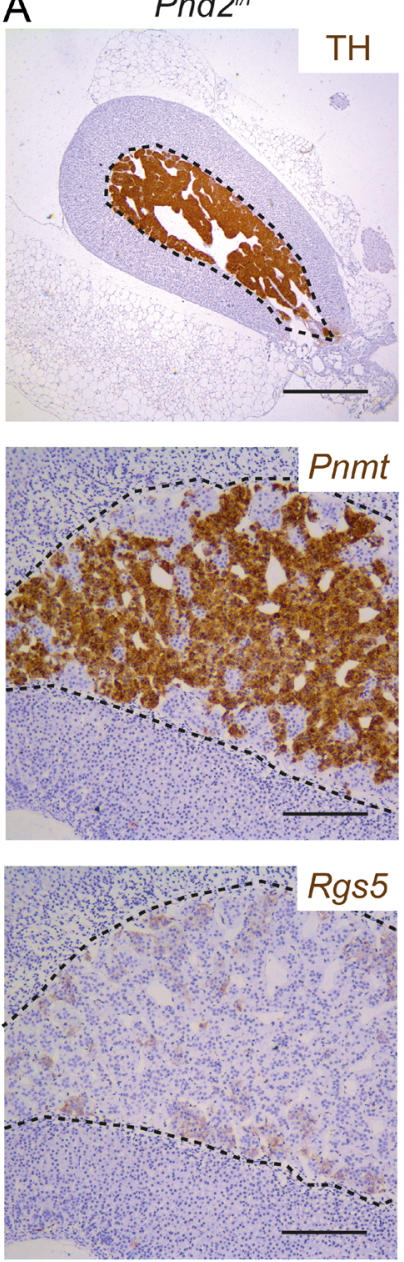

Phd2 2ff; THCreER
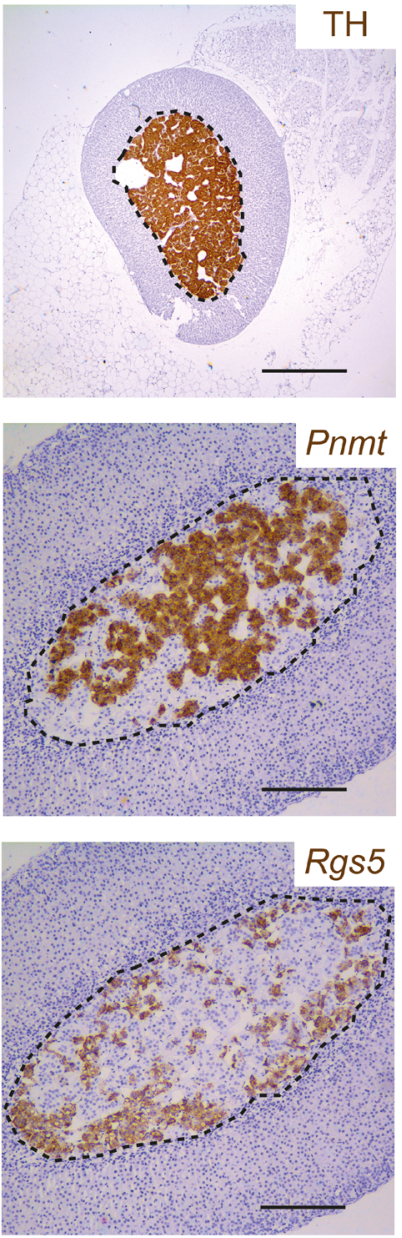

Phd2/f
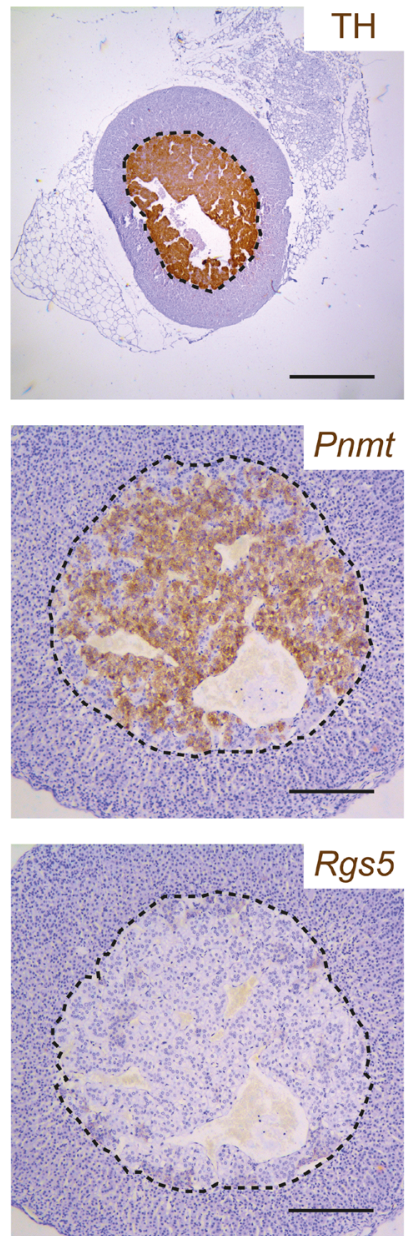

Phd 2ff:RosaCreER
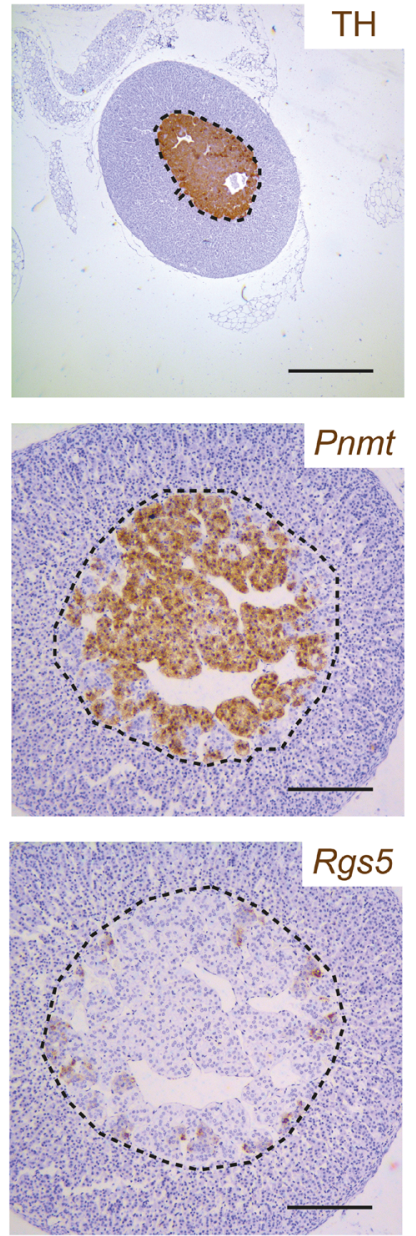

B
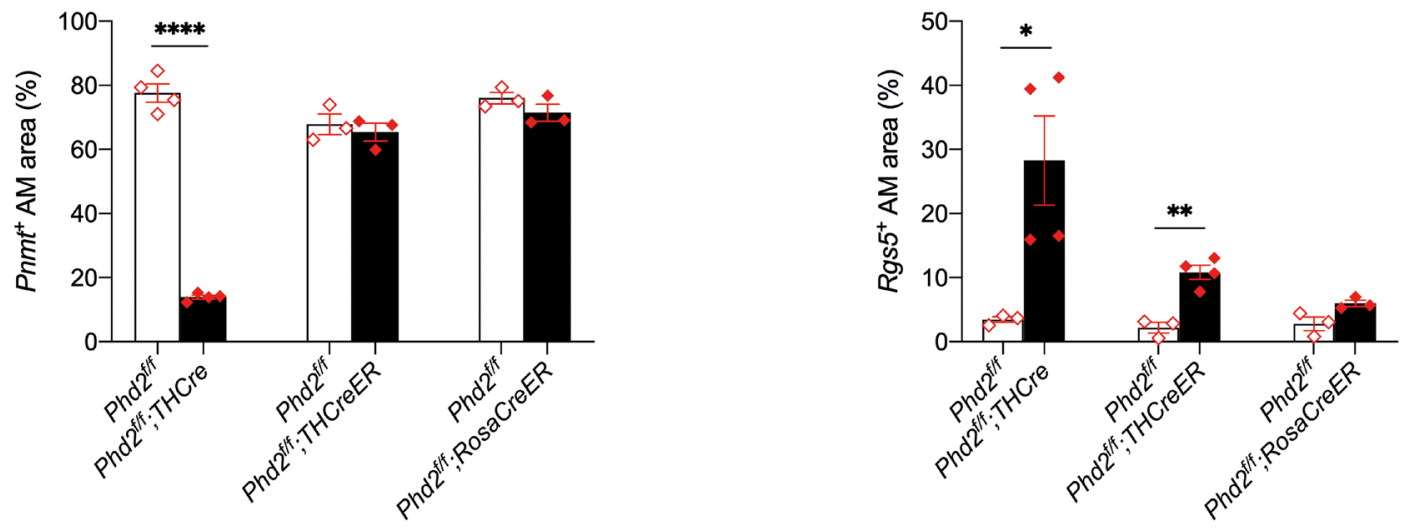

\section{Figure 6}

Effect of adult-onset Phd2 inactivation on morphology and gene expression in the AM. (A) Representative images of TH protein and Pnmt and Rgs5 mRNA in adrenal glands from Phd2ff; THCreER, Phd2ff; RosaCreER (and their respective Phd2fff controls) killed 3 months or 17 days post tamoxifen treatment, respectively. Harris haematoxylin counterstain (blue). Scale bars: $0.5 \mathrm{~mm}$ (top row) or $0.2 \mathrm{~mm}$ (bottom two rows). (B) Quantification of the percentage of Pnmt' and Rgs5+ AM area; AMs from Phd2fff; THCre, Phd2ff; THCreER and Phd2ff; RosaCreER mice (filled bars and rhombi) and their respective controls (open bars and rhombi). Bars show mean \pm S.E.M. Data within individual genotype groups were compared by unpaired two-tailed Student's $t$-tests: ${ }^{*} P<0.05$, $\star * P<0.01, * * \star * P<0.0001$. Adult-onset $P h d 2$ inactivation did not phenocopy morphological abnormalities or Pnmt loss in the AM observed with early-onset Phd2 inactivation, although a small but significant induction in Rgs $5^{+}$was noted within the Pnmt- cells of Phd2ff; THCreER AMs.

https://erc.bioscientifica.com https://doi.org/10.1530/ERC-21-0211 (c) 2021 The authors Published by Bioscientifica Ltd. Printed in Great Britain

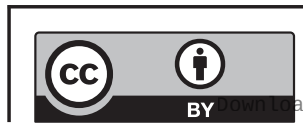

This work is licensed under a Creative Commons Attribution 4.0 International License. ded from Bioscientifica.com at $04 / 26 / 2023$ 11:46:24AM 

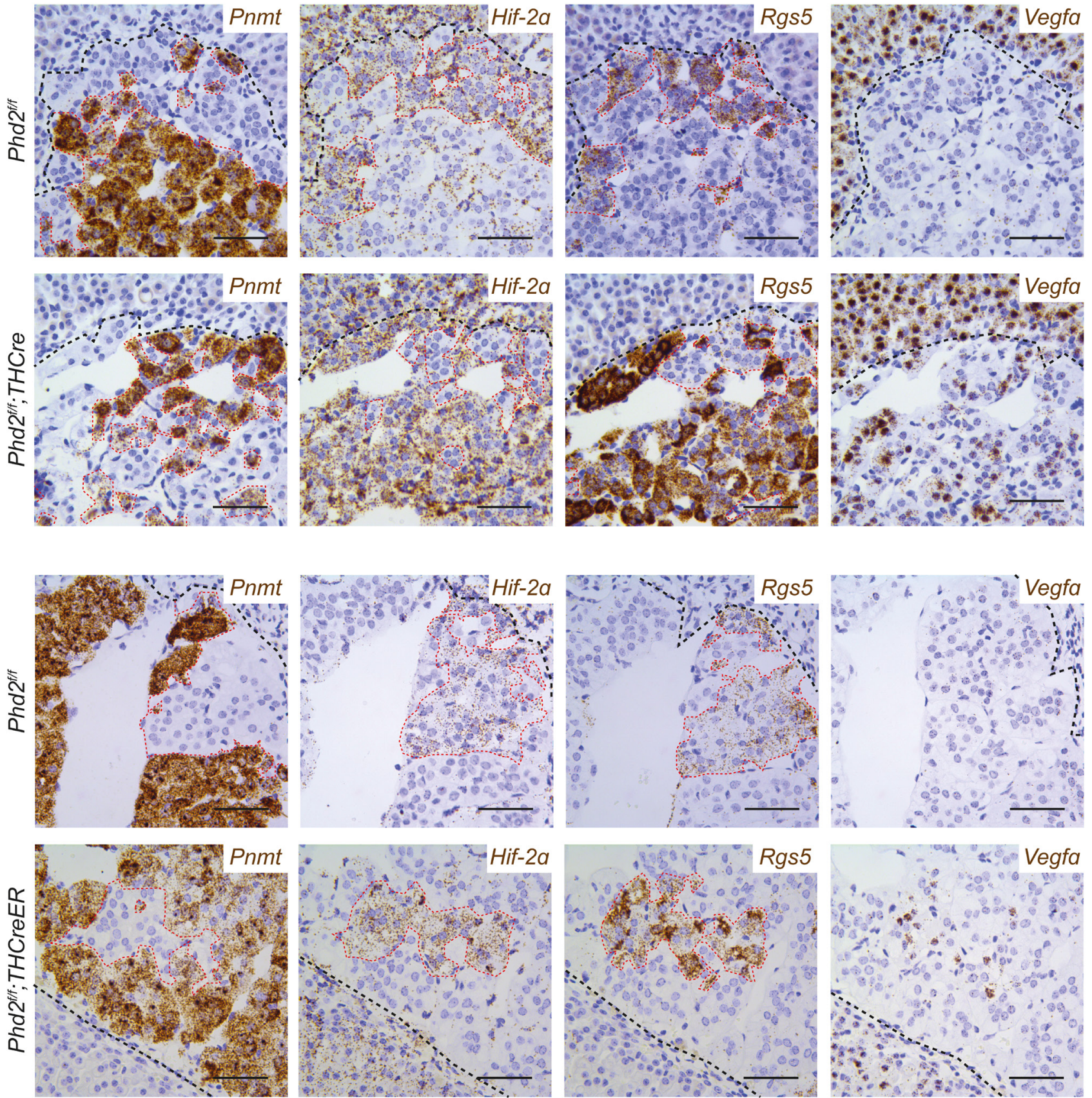

\section{Figure 7}

Spatial distribution of gene expression in the AM with constitutive or adult-onset Phd2 inactivation. Representative images of in situ hybridisation for Pnmt, Hif-2 $\alpha$, Rgs5 and Vegfa mRNA in Phd2ff; THCre (constitutive) or Phd2ff; THCreER (adult-onset) mice and their respective controls. Pnmt expression in

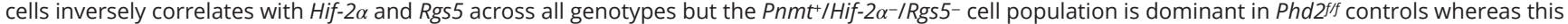

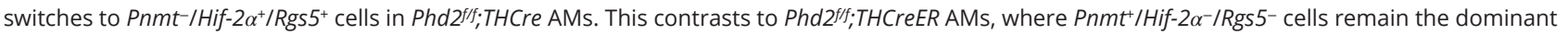
population; additionally, Rgs 5 and Vegfa are induced within the minority population of Pnmt- $/ H i f-2 \alpha^{+} / R g s 5^{+}$cells compared to control mice. Harris haematoxylin counterstain (blue). Scale bars: $0.05 \mathrm{~mm}$.

PHD2-dependent cell differentiation changes predisposing to subsequent tumourigenesis. Interestingly, inactivation of the related HIF prolyl hydroxylase isoform PHD3 prevents developmental culling of neurons, and this has also been proposed to pre-dispose to tumours (Lee et al. 2005,

https://erc.bioscientifica.com https://doi.org/10.1530/ERC-21-0211

(c) 2021 The authors Published by Bioscientifica Ltd. Printed in Great Britain
Bishop et al. 2008). Consistent with the relevance of our findings to the human syndrome, we found that changes in adrenal morphology and gene expression were ablated by inactivation of $H i f-2 \alpha$, but not Hif-1 $\alpha$, in line with the observation that activating mutations in $H I F-2 \alpha$, but not 
$H I F-1 \alpha$, are associated with human PPGL (Buffet et al. 2020). The finding of extra-adrenal tissue reported in our study might also be relevant to the not infrequent occurrence of chromaffin cell tumours at extra-adrenal sites (Tischler 2008). Although a correlation between the distribution of chromaffin tissue and paraganglioma has been reported (Coupland 1965), our data raises the possibility that these extra-adrenal PGLs may arise due to impaired migration and differentiation of sympathetic precursors that would normally populate the adrenal primordia to acquire features of mature, adrenergic chromaffin cells during development (Furlan et al. 2017, Hanemaaijer et al. 2021).

The precise action of HIF-2 in promoting abnormal adrenal development will require further investigation, including the dissection of effects on differentiation, migration and interaction with other processes including innervation (Vollmer 1996). Notably, inactivation of Hif-2 $\alpha$ in the setting of Phd2 inactivation (Supplementary Fig. 5) did not obliterate Pnmt-/Rgs5+ cells in Phd2f/f;Hif-2 $\alpha^{f / f}$; THCre mice. Furthermore, in the normal AM, Pnmt- cells that show increased Hif- $2 \alpha$ and Rgs 5 mRNA levels did not express detectable levels of HIF- $2 \alpha$ protein (data not shown). Thus, in this cell population, HIF-2 does not appear necessary to generate a Pnmt-/Hif-2 $\alpha^{+} / R g s 5^{+}$or noradrenergic phenotype; nor is HIF-2 necessary for PNMT acquisition in adrenergic cells, as evidenced from the normal AMs in Hif-2 $\alpha^{f / f} ;$ THCre mice (Macias et al. 2018) as well as in Phd2fff;Hif-2 $\alpha^{f / f}$;THCre mice reported here. Rather, excess stabilisation of HIF-2 $\alpha$ acts in some way to interrupt a developmental programme that ordinarily generates Pnmt ${ }^{+}$in other AM cells.

Although Phd2 inactivation resulted in changes characteristic of pseudohypoxic PCCs, in this model we did not detect frank PCCs in $\sim 3$ month-old mice. Since PCC development might have a longer latency, we also analysed older cohorts of animals but again did not observe PCC development in $n=7$ Phd2ff; THCre and littermate control mice analysed aged $\sim 18$ months. However, we did observe three $\mathrm{TH}^{+}$, chromogranin $\mathrm{A}^{+}$nodules of chromaffin cells amongst a group of $n=11$ Phd2fff;Hif- $1 \alpha f / f$; THCre mice aged in parallel (Supplementary Fig. 6). The significance of this is unclear, but HIF- $1 \alpha$ has been reported to act as a tumour suppressor in VHL-associated renal clear cell carcinoma (Shen et al. 2011), and it may be that HIF-1 also has a tumour suppressive role in this context.

Our findings have relevance for both experimental and clinical research into PCC. They suggest that it may also be useful to revisit mouse models of pseudohypoxic PCC including models of inactivation of $S d h x$ that have not resulted in PCC (Piruat et al. 2004, Bayley et al. 2009,
Díaz-Castro et al. 2012, Macias et al. 2014, LepoutreLussey et al. 2016, Al Khazal et al. 2021), to assess whether a switch from Pnmt $/$ Hif-2 $\alpha^{-} /$Rgs5 $^{-}$to Pnmt-/ Hif- $2 \alpha^{+} / R_{g s} 5^{+}$cell populations also occurs in these settings. At the clinical level, our findings suggest that attempts at prevention or treatment should rationally include a focus on early life. Interestingly, patients with congenital cyanotic heart disease (a condition associated with life-long hypoxaemia beginning perinatally) have been reported to be susceptible to PCCs, many of which harbour sporadic HIF-2 $\alpha$ mutations (Opotowsky et al. 2015, Vaidya et al. 2018); our data suggests that it is the early-onset hypoxia in these patients which predisposes to subsequent PCC formation.

Interestingly, the HIF-2-dependent effects of Phd2 inactivation, including paraganglioma-like carotid bodies (Fielding et al. 2018), are strikingly different from those of $V h l$ inactivation in catecholaminergic tissues using the same THCre promoter as in this study, which results in atrophy of multiple organs of the sympathetic nervous system, including the AM and the carotid body (Macias et al. 2014). There is a complex association between mutations in VHL disease and the tumour phenotypes, with type $2 \mathrm{VHL}$ mutations that result in PCCs having only modest (or minimal) effects on HIF dysregulation, while type 1 mutations do not develop PCCs and result in greater HIF stabilisation (Kaelin 2008). Although levels of HIF activation have not been compared directly, our findings support the hypothesis that more moderate HIF activation associated with inactivation of a single $P H D$ (as opposed to another function of VHL distinct from an action on HIF) is the most likely explanation for this paradox.

Several other aspects of the dysregulated gene expression pattern merit comment. In particular, several genes that were upregulated in Phd2-inactivated AMs (including Rgs5, Cox4i2 and Adora2a) are very highly and specifically expressed in normal carotid body type I cells (Zhou et al. 2016), a cell type that responds to low oxygen with the rapid release of neurotransmitters to mediate hypoxic ventilatory control in what is termed acute oxygen sensing (Gao et al. 2019). Chromaffin cells are also reportedly acutely oxygen-sensitive during development, but this is lost in adulthood (Thompson et al. 1997). The retention of an immature phenotype in AMs with Phd2 inactivation may extend beyond gene expression to include retention of acute oxygen sensitivity. In future studies, it will be of interest to determine the extent to which Phd2 inactivation in the AM recreates oxygen sensitivity in the adult.

This work is licensed under a Creative Commons Attribution 4.0 International License. ded from Bioscientifica.com at 04/26/2023 11:46:24AM 


\section{Supplementary materials}

This is linked to the online version of the paper at https://doi.org/10.1530/ ERC-21-0211.

\section{Declaration of interest}

PJ R is a scientific co-founder of, and holds equity in, ReOx Ltd, a University spin-out company that seeks to develop therapeutic HIF hydroxylases inhibitors and a non-executive director of Immunocore Holdings PLC. E J H is employed under the Cambridge Experimental Medicine Initiative, partly funded by AstraZeneca, although they have not been involved in this project. The other authors declare no financial interests.

\section{Funding}

Funding for the work was received from the Oxford Branch of the Ludwig Institute for Cancer Research, the Wellcome Trust (106241/Z/14/Z) and the Paradifference Foundation. This work was also supported by the Francis Crick Institute, which receives its core funding from Cancer Research UK (FC001501), the UK Medical Research Council (FC001501), and the Wellcome Trust (FC001501). L E was sponsored by an MD fellowship from Boehringer Ingelheim Fonds; J D C C L by a FAPESP fellowship (2018/20083-1); S K by a Christopher Welch Scholarship and the Clarendon Fund.

\section{Author contribution statement}

Experiments were designed by $L E, M P B, P J R$ and T B. Data were collected and analysed by all authors. Manuscript was prepared by $L E, M P B, P J R$ and $T B$ and reviewed by all authors. Figures were prepared and statistical analyses performed by $L E$ and $M P B$ with input from other authors. $P J R$ and $T$ B conceived the study and managed the project. P J R and T B are co-senior authors.

\section{Acknowledgement}

The authors thank Douglas Dos Santos Passos and Jade Harris for their help in various forms.

\section{References}

Al Khazal F, Kang S, Nelson Holte M, Choi DS, Singh R, Ortega-Sáenz P, López-Barneo J \& Maher 3rd LJ 2021 Unexpected obesity, rather than tumorigenesis, in a conditional mouse model of mitochondrial complex II deficiency. FASEB Journal 35 e21227. (https://doi org/10.1096/fj.202002100R)

Bankhead P, Loughrey MB, Fernández JA, Dombrowski Y, McArt DG, Dunne PD, Mcquaid S, Gray RT, Murray LJ, Coleman HG, et al. 2017 QuPath: open source software for digital pathology image analysis. Scientific Reports 7 16878. (https://doi.org/10.1038/s41598-017-17204-5)

Bayley JP, Van Minderhout I, Hogendoorn PC, Cornelisse CJ, Van Der Wal A, Prins FA, Teppema L, Dahan A, Devilee P \& Taschner PE 2009 Sdhd and SDHD/H19 knockout mice do not develop paraganglioma or pheochromocytoma. PLoS ONE 4 e7987. (https://doi.org/10.1371/ journal.pone.0007987)

Bishop T \& Ratcliffe PJ 2014 Signaling hypoxia by hypoxia-inducible factor protein hydroxylases: a historical overview and future perspectives. Hypoxia 2 197-213. (https://doi.org/10.2147/HP.S47598)
Bishop T, Gallagher D, Pascual A, Lygate CA, De Bono JP, Nicholls LG Ortega-Saenz P, Oster H, Wijeyekoon B, Sutherland AI, et al. 2008 Abnormal sympathoadrenal development and systemic hypotension in PHD3-/- mice. Molecular and Cellular Biology 28 3386-3400. (https:// doi.org/10.1128/MCB.02041-07)

Bishop T, Talbot NP, Turner PJ, Nicholls LG, Pascual A, Hodson EJ, Douglas G, Fielding JW, Smith TG, Demetriades M, et al. 2013 Carotid body hyperplasia and enhanced ventilatory responses to hypoxia in mice with heterozygous deficiency of PHD2. Journal of Physiology 591 3565-3577. (https://doi.org/10.1113/jphysiol.2012.247254)

Buffet A, Burnichon N, Favier J \& Gimenez-Roqueplo AP 2020 An overview of 20 years of genetic studies in pheochromocytoma and paraganglioma. Best Practice and Research: Clinical Endocrinology and Metabolism 34 101416. (https://doi.org/10.1016/j.beem.2020.101416)

Burnichon N, Vescovo L, Amar L, Libe R, De Reynies A, Venisse A Jouanno E, Laurendeau I, Parfait B, Bertherat J, et al. 2011 Integrative genomic analysis reveals somatic mutations in pheochromocytoma and paraganglioma. Human Molecular Genetics 20 3974-3985. (https:// doi.org/10.1093/hmg/ddr324)

Chan WH, Komada M, Fukushima T, Southard-Smith EM, Anderson CR \& Wakefield MJ 2019 RNA-seq of isolated chromaffin cells highlights the role of sex-linked and imprinted genes in adrenal medulla development. Scientific Reports 9 3929. (https://doi.org/10.1038/ s41598-019-40501-0)

Cheng X, Prange-Barczynska M, Fielding JW, Zhang M, Burrell AL, Lima JD, Eckardt L, Argles I, Pugh CW, Buckler KJ, et al. 2020 Marked and rapid effects of pharmacological HIF-2 $\alpha$ antagonism on hypoxic ventilatory control. Journal of Clinical Investigation 130 2237-2251. (https://doi.org/10.1172/JCI133194)

Choueiri TK \& Kaelin Jr WG 2020 Targeting the HIF2-VEGF axis in renal cell carcinoma. Nature Medicine 26 1519-1530. (https://doi. org/10.1038/s41591-020-1093-z)

Coupland RE 1965 The Natural History of Chromaffin Cell. London, UK: Longmans.

Coupland RE \& Hopwood D 1966 Mechanism of a histochemical reaction differentiating between adrenaline- and noradrenaline-storing cells in the electron microscope. Nature 209 590-591. (https://doi. org/10.1038/209590a0)

Cramer T, Yamanishi Y, Clausen BE, Forster I, Pawlinski R, Mackman N, Haase VH \& Jaenisch R, Corr M, Nizet V 2003 HIF-1alpha is essential for myeloid cell-mediated inflammation. Cell 112 645-657. (https:// doi.org/10.1016/s0092-8674(03)00154-5)

Crona J, Taïeb D \& Pacak K 2017 New perspectives on pheochromocytoma and paraganglioma: toward a molecular classification. Endocrine Reviews 38 489-515. (https://doi.org/10.1210/er.2017-00062)

Dahia PL, Ross KN, Wright ME, Hayashida CY, Santagata S, Barontini M, Kung AL, Sanso G, Powers JF, Tischler AS, et al. 2005 A HIF1alpha regulatory loop links hypoxia and mitochondrial signals in pheochromocytomas. PLoS Genetics 1 72-80. (https://doi.org/10.1371/ journal.pgen.0010008)

Díaz-Castro B, Pintado CO, García-Flores P, López-Barneo J \& Piruat JI 2012 Differential impairment of catecholaminergic cell maturation and survival by genetic mitochondrial complex II dysfunction. Molecular and Cellular Biology 32 3347-3357. (https://doi.org/10.1128/ MCB.00128-12)

Eisenhofer G, Walther MM, Huynh TT, Li ST, Bornstein SR, Vortmeyer A, Mannelli M, Goldstein DS, Linehan WM, Lenders JW, et al. 2001 Pheochromocytomas in von Hippel-Lindau syndrome and multiple endocrine neoplasia type 2 display distinct biochemical and clinical phenotypes. Journal of Clinical Endocrinology and Metabolism $\mathbf{8 6}$ 1999-2008. (https://doi.org/10.1210/jcem.86.5.7496)

Favier J, Brière JJ, Burnichon N, Rivière J, Vescovo L, Benit P, GiscosDouriez I, De Reyniès A, Bertherat J, Badoual C, et al. 2009 The Warburg effect is genetically determined in inherited pheochromocytomas. PLoS ONE 4 e7094. (https://doi.org/10.1371/ journal.pone.0007094)

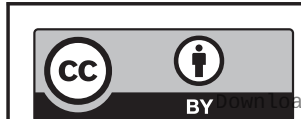

This work is licensed under a Creative Commons Attribution 4.0 International License. 
Favier J, Buffet A \& Gimenez-Roqueplo AP 2012 HIF2A mutations in paraganglioma with polycythemia. New England Journal of Medicine 367 2161; author reply 2161-2162. (https://doi.org/10.1056/ NEJMc1211953)

Fielding JW, Hodson EJ, Cheng X, Ferguson DJP, Eckardt L, Adam J, Lip P, Maton-Howarth M, Ratnayaka I, Pugh CW, et al. 2018 PHD2 inactivation in Type I cells drives HIF-2alpha-dependent multilineage hyperplasia and the formation of paraganglioma-like carotid bodies. Journal of Physiology 596 4393-4412. (https://doi.org/10.1113/ JP275996)

Fishbein L \& Wilkerson MD 2018 Chromaffin cell biology: inferences from the Cancer Genome Atlas. Cell and Tissue Research 372 339-346. (https://doi.org/10.1007/s00441-018-2795-0)

Fishbein L, Leshchiner I, Walter V, Danilova L, Robertson AG, Johnson AR, Lichtenberg TM, Murray BA, Ghayee HK, Else T, et al. 2017 Comprehensive molecular characterization of pheochromocytoma and paraganglioma. Cancer Cell 31 181-193. (https://doi.org/10.1016/j. ccell.2017.01.001)

Furlan A, Dyachuk V, Kastriti ME, Calvo-Enrique L, Abdo H, Hadjab S, Chontorotzea T, Akkuratova N, Usoskin D, Kamenev D, et al. 2017 Multipotent peripheral glial cells generate neuroendocrine cells of the adrenal medulla. Science $\mathbf{3 5 7}$ eaal3753. (https://doi.org/10.1126/ science.aal3753)

Gao L, Ortega-Sáenz P \& López-Barneo J 2019 Acute oxygen sensing-Role of metabolic specifications in peripheral chemoreceptor cells. Respiratory Physiology and Neurobiology 265 100-111. (https://doi. org/10.1016/j.resp.2018.08.007)

Gruber M, Hu CJ, Johnson RS, Brown EJ, Keith B \& Simon MC 2007 Acute postnatal ablation of Hif-2alpha results in anemia. PNAS 104 2301-2306. (https://doi.org/10.1073/pnas.0608382104)

Hanemaaijer ES, Margaritis T, Sanders K, Bos FL, Candelli T, Al-Saati H, Van Noesel MM, Meyer-Wentrup FAG, Van De Wetering M, Holstege FCP, et al. 2021 Single-cell atlas of developing murine adrenal gland reveals relation of Schwann cell precursor signature to neuroblastoma phenotype. PNAS 118 e2022350118. (https://doi. org/10.1073/pnas.2022350118)

Hodson EJ, Nicholls LG, Turner PJ, Llyr R, Fielding JW, Douglas G, Ratnayaka I, Robbins PA, Pugh CW, Buckler KJ, et al. 2016 Regulation of ventilatory sensitivity and carotid body proliferation in hypoxia by the PHD2/HIF-2 pathway. Journal of Physiology 594 1179-1195. (https://doi.org/10.1113/JP271050)

Jin Y, An X, Ye Z, Cully B, Wu J \& Li J 2009 RGS5, a hypoxia-inducible apoptotic stimulator in endothelial cells. Journal of Biological Chemistry 284 23436-23443. (https://doi.org/10.1074/jbc.M109.032664)

Kaelin Jr WG 2008 The von Hippel-Lindau tumour suppressor protein: O2 sensing and cancer. Nature Reviews: Cancer 8 865-873. (https://doi. org/10.1038/nrc2502)

Ladroue C, Carcenac R, Leporrier M, Gad S, Le Hello C, Galateau-Salle F, Feunteun J, Pouysségur J, Richard S \& Gardie B 2008 PHD2 mutation and congenital erythrocytosis with paraganglioma. New England Journal of Medicine 359 2685-2692. (https://doi.org/10.1056/ NEJMoa0806277)

Lee S, Nakamura E, Yang H, Wei W, Linggi MS, Sajan MP, Farese RV, Freeman RS, Carter BD, Kaelin Jr WG, et al. 2005 Neuronal apoptosis linked to EglN3 prolyl hydroxylase and familial pheochromocytoma genes: developmental culling and cancer. Cancer Cell 8 155-167. (https://doi.org/10.1016/j.ccr.2005.06.015)

Lepoutre-Lussey C, Thibault C, Buffet A, Morin A, Badoual C, Bénit P, Rustin P, Ottolenghi C, Janin M, Castro-Vega LJ, et al. 2016 From Nf1 to Sdhb knockout: successes and failures in the quest for animal models of pheochromocytoma. Molecular and Cellular Endocrinology $\mathbf{4 2 1}$ 40-48. (https://doi.org/10.1016/j.mce.2015.06.027)

Lindeberg J, Usoskin D, Bengtsson H, Gustafsson A, Kylberg A Söderström S \& Ebendal T 2004 Transgenic expression of Cre recombinase from the tyrosine hydroxylase locus. Genesis 40 67-73. (https://doi.org/10.1002/gene.20065)
Lorenzo FR, Yang C, Ng Tang Fui M, Vankayalapati H, Zhuang Z, Huynh T, Grossmann M, Pacak K \& Prchal JT 2013 A novel EPAS1/HIF2A germline mutation in a congenital polycythemia with paraganglioma. Journal of Molecular Medicine 91 507-512. (https://doi.org/10.1007/ s00109-012-0967-z)

Macias D, Fernandez-Aguera MC, Bonilla-Henao V \& Lopez-Barneo J 2014 Deletion of the von Hippel-Lindau gene causes sympathoadrenal cell death and impairs chemoreceptor-mediated adaptation to hypoxia. EMBO Molecular Medicine 6 1577-1592. (https://doi.org/10.15252/ emmm.201404153)

Macias D, Cowburn AS, Torres-Torrelo H, Ortega-Saenz P, Lopez-Barneo J \& Johnson RS 2018 HIF-2alpha is essential for carotid body development and function. eLife 7 e34681. (https://doi.org/10.7554/ eLife.34681)

Mazzone M, Dettori D, De Oliveira RL, Loges S, Schmidt T, Jonckx B, Tian YM, Lanahan AA, Pollard P, De Almodovar CR, et al. 2009 Heterozygous deficiency of PHD2 restores tumor oxygenation and inhibits metastasis via endothelial normalization. Cell 136 839-851. (https://doi.org/10.1016/j.cell.2009.01.020)

Nagendran M, Riordan DP, Harbury PB \& Desai TJ 2018 Automated celltype classification in intact tissues by single-cell molecular profiling. eLife 7 e30510. (https://doi.org/10.7554/eLife.30510)

Opotowsky AR, Moko LE, Ginns J, Rosenbaum M, Greutmann M, Aboulhosn J, Hageman A, Kim Y, Deng LX, Grewal J, et al. 2015 Pheochromocytoma and paraganglioma in cyanotic congenital heart disease. Journal of Clinical Endocrinology and Metabolism $\mathbf{1 0 0}$ 1325-1334. (https://doi.org/10.1210/jc.2014-3863)

Park WJ, Brenner O, Kogot-Levin A, Saada A, Merrill Jr AH, Pewzner-Jung Y \& Futerman AH 2015 Development of pheochromocytoma in ceramide synthase 2 null mice. Endocrine-Related Cancer 22 623-632. (https://doi.org/10.1530/ERC-15-0058)

Piruat JI, Pintado CO, Ortega-Sáenz P, Roche M \& López-Barneo J 2004 The mitochondrial SDHD gene is required for early embryogenesis, and its partial deficiency results in persistent carotid body glomus cell activation with full responsiveness to hypoxia. Molecular and Cellular Biology 24 10933-10940. (https://doi.org/10.1128/MCB.24.24.1093310940.2004)

Rotolo T, Smallwood PM, Williams J \& Nathans J 2008 Geneticallydirected, cell type-specific sparse labeling for the analysis of neuronal morphology. PLoS ONE 3 e4099. (https://doi.org/10.1371/journal. pone.0004099)

Semenza GL 2019 Pharmacologic targeting of hypoxia-inducible factors. Annual Review of Pharmacology and Toxicology 59 379-403. (https://doi. org/10.1146/annurev-pharmtox-010818-021637)

Shen C, Beroukhim R, Schumacher SE, Zhou J, Chang M, Signoretti S \& Kaelin Jr WG 2011 Genetic and functional studies implicate HIF1 $\alpha$ as a 14q kidney cancer suppressor gene. Cancer Discovery $1222-235$. (https://doi.org/10.1158/2159-8290.CD-11-0098)

Smith-Hicks CL, Sizer KC, Powers JF, Tischler AS \& Costantini F 2000 C-cell hyperplasia, pheochromocytoma and sympathoadrenal malformation in a mouse model of multiple endocrine neoplasia type 2B. EMBO Journal 19 612-622. (https://doi.org/10.1093/ emboj/19.4.612)

Tai TC, Wong-Faull DC, Claycomb R \& Wong DL 2009 Hypoxic stressinduced changes in adrenergic function: role of HIF1 alpha. Journal of Neurochemistry 109 513-524. (https://doi. $\operatorname{org} / 10.1111 / \mathrm{j} .1471-4159.2009 .05978 . x)$

Thompson RJ, Jackson A \& Nurse CA 1997 Developmental loss of hypoxic chemosensitivity in rat adrenomedullary chromaffin cells. Journal of Physiology 498 503-510. (https://doi.org/10.1113/jphysiol.1997.sp021876)

Tischler AS 2008 Pheochromocytoma and extra-adrenal paraganglioma: updates. Archives of Pathology and Laboratory Medicine 132 1272-1284. (https://doi.org/10.5858/2008-132-1272-PAEPU)

Toledo RA 2017 New HIF2 $\alpha$ inhibitors: potential implications as therapeutics for advanced pheochromocytomas and paragangliomas. EndocrineRelated Cancer 24 C9-C19. (https://doi.org/10.1530/ERC-16-0479) 
Toledo RA, Qin Y, Srikantan S, Morales NP, Li Q, Deng Y, Kim SW, Pereira MA, Toledo SP, Su X, et al. 2013 In vivo and in vitro oncogenic effects of HIF2A mutations in pheochromocytomas and paragangliomas. Endocrine-Related Cancer 20 349-359. (https://doi. org/10.1530/ERC-13-0101)

Vaidya A, Flores SK, Cheng ZM, Nicolas M, Deng Y, Opotowsky AR, Lourenço Jr DM, Barletta JA, Rana HQ, Pereira MA, et al. 2018 EPAS1 mutations and paragangliomas in cyanotic congenital heart disease. New England Journal of Medicine 378 1259-1261. (https://doi. org/10.1056/NEJMc1716652)

Verhofstad AA, Hökfelt T, Goldstein M, Steinbusch HW \& Joosten HW 1979 Appearance of tyrosine hydroxylase, aromatic amino-acid decarboxylase, dopamine beta-hydroxylase and phenylethanolamine $\mathrm{N}$-methyltransferase during the ontogenesis of the adrenal medulla: an immunohistochemical study in the rat. Cell and Tissue Research 200 1-13. (https://doi.org/10.1007/ BF00236882)

Vollmer RR 1996 Selective neural regulation of epinephrine and norepinephrine cells in the adrenal medulla - cardiovascular implications. Clinical and Experimental Hypertension 18 731-751. (https://doi.org/10.3109/10641969609081778)

Vooijs M, Jonkers J \& Berns A 2001 A highly efficient ligand-regulated Cre recombinase mouse line shows that LoxP recombination is position dependent. EMBO Reports 2 292-297. (https://doi.org/10.1093/emboreports/kve064)

Waldmann J, Fendrich V, Holler J, Buchholz M, Heinmöller E, Langer P, Ramaswamy A, Samans B, Walz MK, Rothmund M, et al. 2010 Microarray analysis reveals differential expression of benign and malignant pheochromocytoma. Endocrine-Related Cancer 17 743-756. (https://doi.org/10.1677/ERC-09-0118)

Welander J, Andreasson A, Brauckhoff M, Bäckdahl M, Larsson C, Gimm O \& Söderkvist P 2014 Frequent EPAS1/HIF2 $\alpha$ exons 9 and 12 mutations in non-familial pheochromocytoma. Endocrine-Related Cancer 21 495-504. (https://doi.org/10.1530/ERC-13-0384)

Yang C, Zhuang Z, Fliedner SM, Shankavaram U, Sun MG, Bullova P, Zhu R, Elkahloun AG, Kourlas PJ, Merino M, et al. 2015 Germ-line PHD1 and PHD2 mutations detected in patients with pheochromocytoma/ paraganglioma-polycythemia. Journal of Molecular Medicine 93 93-104. (https://doi.org/10.1007/s00109-014-1205-7)

Zhou T, Chien MS, Kaleem S \& Matsunami H 2016 Single cell transcriptome analysis of mouse carotid body glomus cells. Journal of Physiology 594 4225-4251. (https://doi.org/10.1113/JP271936)

Zhuang Z, Yang C, Lorenzo F, Merino M, Fojo T, Kebebew E, Popovic V, Stratakis CA, Prchal JT \& Pacak K 2012 Somatic HIF2A gain-of-function mutations in paraganglioma with polycythemia. New England Journal of Medicine 367 922-930. (https://doi.org/10.1056/NEJMoa1205119)

Received in final form 1 September 2021

Accepted 20 September 2021

Accepted Manuscript published online 20 September 2021 (c) 2021 The authors Published by Bioscientifica Ltd. Printed in Great Britain
This work is licensed under a Creative Commons Attribution 4.0 International License.

ded from Bioscientifica.com at 04/26/2023 11:46:24AM 